\title{
THE PASSING OF THE LOLO TRAIL
}

\author{
Elers Koch
}

\author{
Assistant Regional Forester \\ Region One, Forest Service \\ Missoula, Montana
}

\begin{abstract}
A somewhat partisan discussion of an important and controversial question of land use, "What shall be done with the low-value back country." The author, who is evidently a wilderness area enthusiast, maintains that the Forest Service has already made a serious mistake in opening the Selway wilderness with roads, and goes so far as to question the worth-whileness of attempting fire control in that country.
\end{abstract}

The Lolo Trail is no more.

The bulldozer blade has ripped out the hoof tracks of Chief Joseph's ponies. The trail was worn deep by centuries of Nezperce and Blackfeet Indians, by Lewis and Clark, by companies of Northwest Company fur traders, by General Howard's cavalry horses, by Captain Mullan, the engineer, and by the early-day forest ranger. It is gone, and in its place there is only the print of the automobile tire in the dust.

What of the camps of fragrant memoryCamp Martin, Rocky Ridge, No Seeum Meadows, Bald Mountain, Indian Grave, Howard Camp, Indian Post Office, Spring Mountain, Cayuse Junction, Packers Meadows? No more will the traveler unsaddle his ponies to roll and graze on the bunch grass of the mountain tops. No more the "mule train coughing in the dust." The trucks roll by on the new Forest Service road, and the old camps are no more than a place to store spare barrels of gasoline.

No more will the mountain man ride the high ridges between the Kooskooskee and the Chopunnish. "Smoking his pipe in the mountains, sniffing the morning cool."

It is now but three hours' drive from the streets of Missoula to the peak where Captain Lewis smoked his pipe and wrote in his journal: "From this elevated spot we have a commanding view of the surrounding mountains, which so completely enclose us that though we have once passed them, we almost despair of ever escaping from them without the assistance of the Indians." Only ten years ago it was just as Lewis and Clark saw it.

So it is everywhere.

The hammer rings in the CCC camp on the remotest waters of the Selway. The bulldozer snorts on Running Creek, that once limit of the back of the beyond. The moose at Elk Summit lift their heads from the lily pads to gaze at the passing motor truck. Major Fenn's beloved Coolwater Divide has become a motor road.

No more can one slip up to the big lick at Powell for a frosty October morning and see the elk in droves. The hunters swarm in motor cars in the public campgrounds.

And all to what end? Only a few years ago the great Clearwater wilderness stretched from the Bitterroot to Kooskia; from the Cedar Creek mines to the Salmon River and beyond. No road and no permanent human habitation marred its primitive nature. There it lay-the last frontier - an appeal to the mind of the few adventurous souls who might wish to penetrate its fastnesses and plunge for weeks beyond human communication.

The Forest Service sounded the note of progress. It opened up the wilderness with roads and telephone lines, and airplane landing fields. It capped the mountain peaks with 
white-painted lookout houses, laced the ridges and streams with a.network of trails and telephone lines, and poured in thousands of firefighters year after year in a vain attempt to control forest fires.

Has all this effort and expenditure of millions of dollars added anything to human good? Is it possible that it was all a ghastly mistake like plowing up the good buffalo grass sod of the dry prairies? Has the country as it stands now as much human value as it had in the nineties when Major Fenn's forest rangers first rode into it?

To answer the questions let us first examine what manner of country this is, and what it is good for. I have before me a map of North Idaho made up on the basis of the combined judgment of the best qualified forest officers, which shows in green Zone 1, the area of unquestioned value for timber production; in white Zone 2, which may possibly have some future timber productive value; and in yellow Zone 3, which, owing to altitude, rugged topography, permanent inaccessibility or inferior timber growth, will never, so far as best present judgment indicates, come into the picture as timber producing land.

The three northern national forests in the state are considerably cut up as to zones, but with green and white greatly predominating on the map. Further south the picture changes. The upper reaches of the North Fork of the Clearwater, the Lochsa, Selway and Salmon Rivers form a great solid block of yellow Zone 3 on the map, covering 3000 square miles, or two million acres in round numbers. This is a different geological formation. Departing from the pre-Cambrian shales of the north end of the state, this is part of the great granite batholith of Central Idaho. It is a country of deep canyons, rushing, boulder-strewn rivers, mountain lakes and high peaks. The decomposed granite soil is thin, coarse-grained and shallow. Prior to the intervention of the Forest Service, the tide of civilization surged round it, and few men entered it. Elk, moose, mountain goats, deer and fur-bearers maintained a natural existence, protected by the country itself.

It seems obvious that whatever value the area may have, it is not for timber production. Rather its value lies in whatever pleasure man may get out of its recreational resources in the way of isolation, scenery, fish and game.

I would that I could turn the clock back and make a plea for preserving the area as it was twenty-five or even five years ago. Alas, it is too late. Roads are such final and irretrievable facts.

The Forest Service built these hundreds of miles of road and these thousands of miles of trail and telephone line for one purpose onlyto facilitate the suppression of forest fires.

The whole history of the Forest Service's attempt to control fire in the back country of the Selway and Clearwater is one of the saddest chapters of the history of a high-minded and efficient public service. In the face of the most heroic effort and the expenditure of millions of dollars and several lives, this country has been swept again and again by most uncontrollable conflagrations. The Lochsa Canyon is burned and reburned from Pete King to Jerry Johnson, and the Selway from the Forks to Moose Creek.

Many fires have been controlled, but when the time is ripe for a conflagration man's efforts have been puny in the face of Nature's forces. I am not criticizing the efforts of others. I have personally taken a considerable part in four major fire campaigns on the Lochsa River, in 1910, 1919, 1929 and 1934. Each year we made a greater effort and threw larger forces of men into the battle, but so far as results are concerned there is little difference between 1919, when crews of thirty or forty men, in a vain but courageous gesture, were trailing the leeward end of each of five or six gigantic fires, and 1934, when firefighters were counted in thousands and the fires swept 180,000 acres [Figures 1 and 2].

When fire gets a good start in the dry firekilled cedar [western red cedar; Thuja plicata 


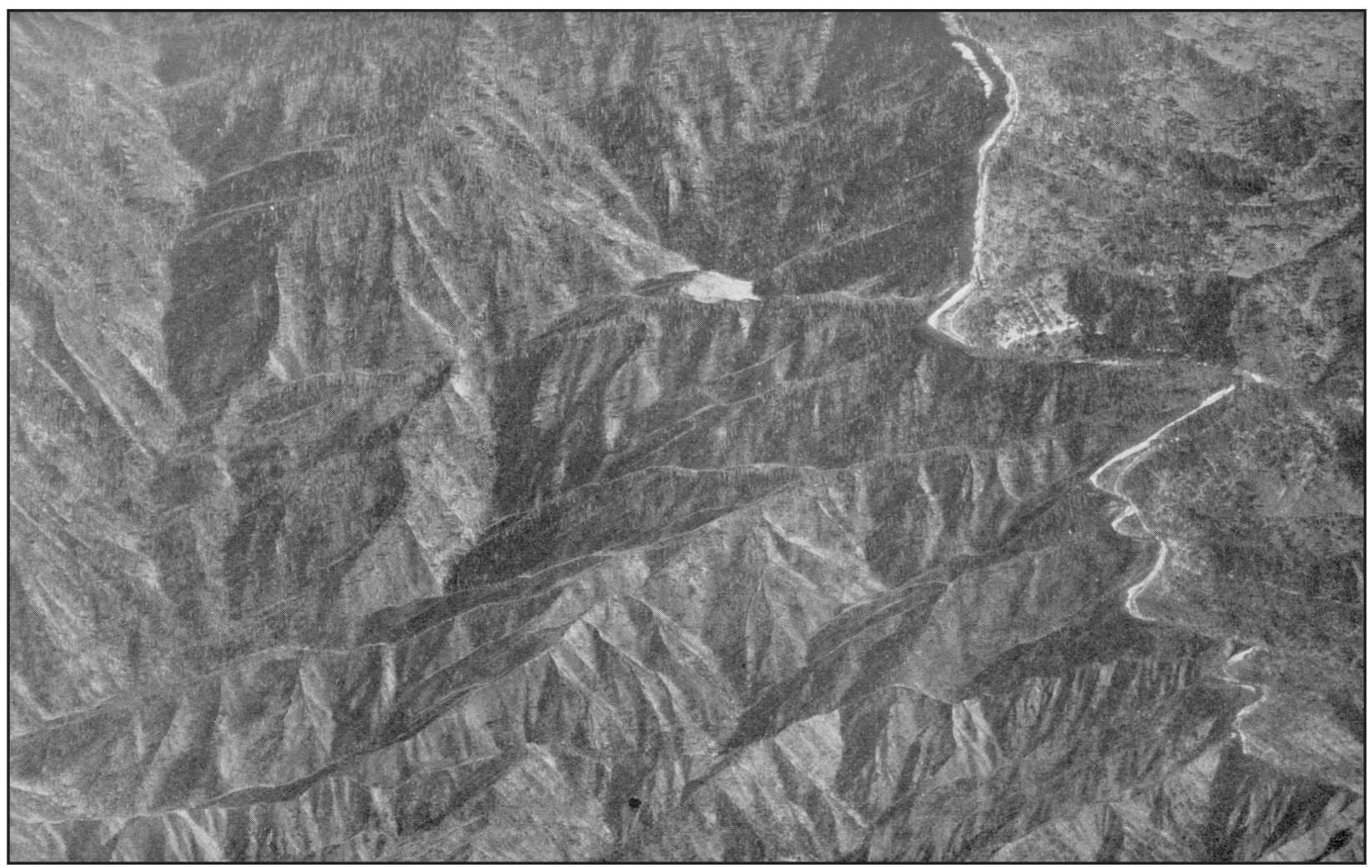

Figure 1. Lochsa River Canyon as it appeared after the 1919 and 1934 fires. 116th Photo Section, Washington National Guard.

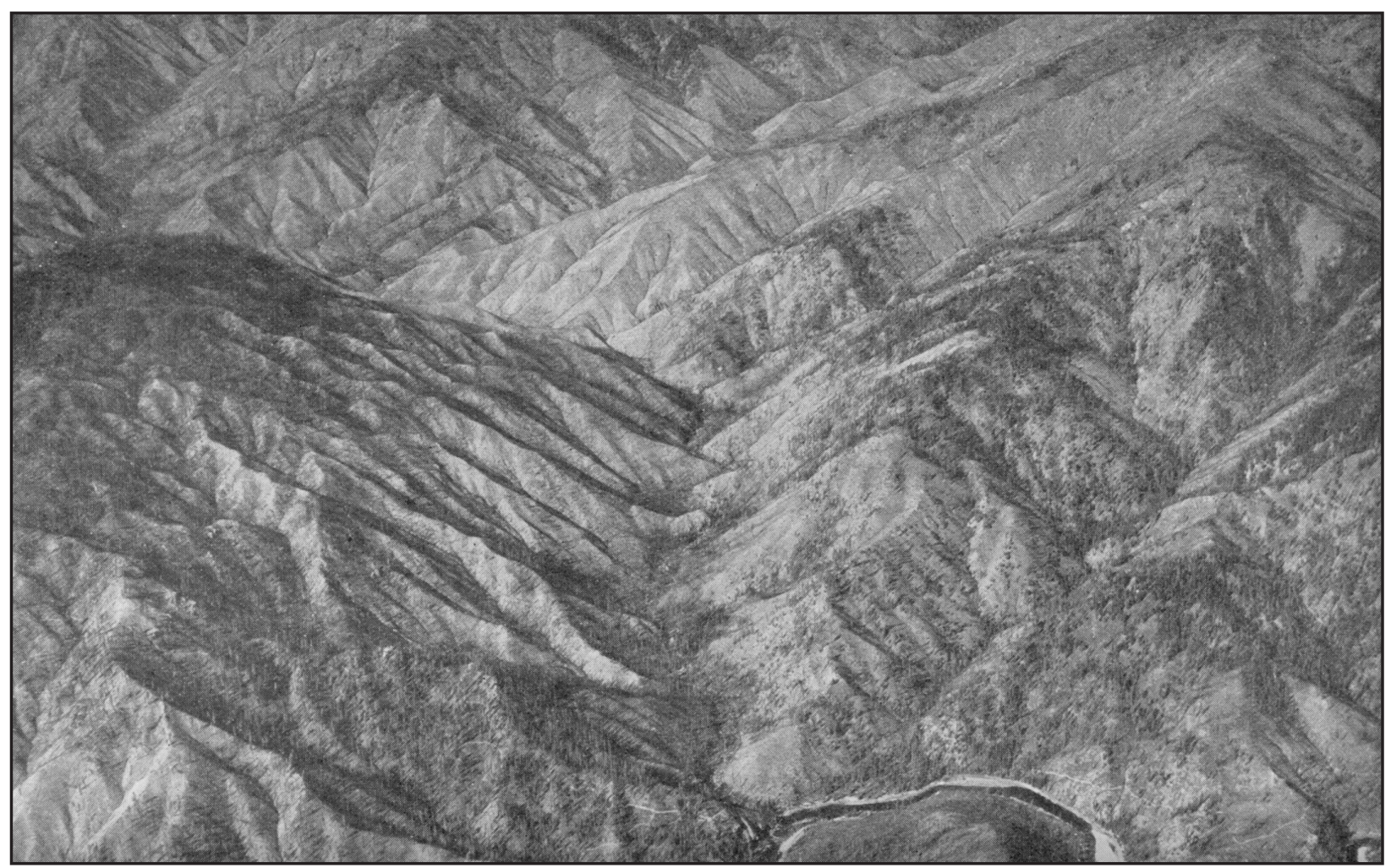

Figure 2. Fish Creek after the 1934 fire. The Lolo Trail is on the high divide in the background, and a Forest Service road shows along the river in the foreground. 116th Photo Section, Washington National Guard. 
Donn ex D. Don] and white [sic; grand] fir [Abies grandis (Douglas ex D. Don) Lindl.] of the Selway and burning conditions are just right, the whole United States Army, if it was on the ground, could do nothing but keep out of the way. After years of experience I have come to the considered conclusion that control of fire in the back country of the Selway and Lochsa drainages is a practical impossibility. I firmly believe that if the Forest Service had never expended a dollar in this country since 1900 there would have been no appreciable difference in the area burned over. It is even possible that, by extinguishing fires in favorable seasons which would have run over a few hundred or a few thousand acres, the stage was only set for the greater conflagrations which went completely beyond fireline control. After all, this country existed and maintained a general timber cover before man was born, and for millions of years before the Forest Service came into being. Surely its existence as wild land capable of sheltering its game and holding the watershed together cannot now be altogether dependent on the efforts of the Forest Service. No important new element has been introduced. Not a single one of the greater fires which have swept the country since 1910 has been man-caused. And even 130 years ago we have Lewis' and Clark's testimony that the Indians habitually set fires for such a trivial purpose as to insure fair weather for a journey.

Since the two-million acre unit under consideration is now part of five national foreststhe Selway, Nezperce, Clearwater, Lolo and Bitterroot-it is difficult to segregate past costs of administration in this country.

The records show that since 1912 the Selway Forest alone has expended the vast sum of $\$ 3,065,000.00$ for all purposes, with receipts of only $\$ 76,000.00$. This does not include the present year's cost, which must have amounted to over half a million dollars. The Selway expenditures for the past four fiscal years, 1931 to 1934 , have averaged $\$ 288,000.00$ annually. If the expenditures by the four other national forests within the low-value zone are added to the Selway, it is probable that the Forest Service has sunk at least five million dollars to date in the area, and will continue to expend at the rate of $\$ 200,000.00$ to $\$ 300,000.00$ a year, with practically no hope of timber-sale receipts or more than a trivial amount in grazing fees to offset the expenditures.

What is the future line of action which should be taken by the Forest Service in this country? There seem to be three alternatives:

1. Continue on about the present basis with some gradual extension of roads, trails, landing fields and other facilities, and about the present force of protection men.

2. If Congress can be induced to appropriate necessary funds, greatly intensify the protection set-up, open all the remaining inaccessible country with roads, and greatly increase the protection forces.

3. Set up a carefully defined unit of about two million acres as a low-value area which does not justify the cost of fire control. Maintain only existing roads and the major trails. Withdraw the entire fire-control organization and retain only a police force of two or three rangers to protect the game and direct recreational use.

The first alternative has been found by twenty years' experience to be practically useless. It has resulted in greatly modifying and to a large extent destroying the special values of a unique and distinctive wilderness area. The results in fire control have been almost negligible. Every really bad fire season has seen great conflagrations sweep completely beyond control, nullifying the results of every fire extinguished in the more favorable seasons. If I could show in color a map of this region with the area burned over since the begin- 
ning of national forest administration, the country would be shocked at the lack of results for the millions expended.

The second alternative, a greatly increased intensification of protection, appears at least more logical than the first. We are now making vast expenditures with little or no results. To double or treble these expenditures and get the desired results would at least give the taxpayers something for their money. It would mean abandoning the wilderness area idea completely and opening the whole country with roads, but that has already progressed so far that there is really no wilderness left, and perhaps we might as well now make up our minds to an automobile recreational use of this area rather than a primitive pack-horse use, provided we are going to tackle the protection job.

The question then arises, even with the most intensive protection system conceivable, can the recurrence of such conflagrations as in 1934, 1929, 1919 and 1910 be prevented? The Selway country presents the toughest fire-control conditions of any area in the United States. There is a combination of a very dry, hot summer with the worst fuel conditions imaginable. The forest, in the lower country and along streams, is largely a cedar, white-fir mixture, much of it already fire killed, and when a fire gets under way in such stands on a bad fire day, look out! Dry cedar, much of it hollow in the center, is an extremely light and inflammable fuel. The hollow trees carry fire like a chimney; the trees fall and shatter into kindling, and the kindling springs to flames. At the same time, shreds of dry cedar bark and sparks from rotten white fir snags throw fire to unbelievable distances ahead.

Can any conceivable system get the best of such conditions? In 1934 the four or five lightning fires which started in the lower Lochsa River presented as favorable set-up for fire-control facilities as the most fantastic conception of an organization would provide. The fires which did most of the damage started right under the eye of several lookouts. Thousands of men in blister-rust crews, road crews and CCC camps were working within a few hours' travel. An excellent road system traversed the area, making it possible to locate most of the fire camps on roads. In spite of the use of all these facilities and the rushing in of the best and most experienced fire overhead in the Region, four fires got completely beyond control and swept an area of 180,000 acres. If similar circumstances arose next year or ten years from now it is not at all likely that any different results could be secured in this particular country. I can only conclude that by doubling or trebling the past fire-control cost, the Forest Service might possibly reduce the area annually burned, but with always the possibility of a great conflagration sweeping beyond control and nullifying all past efforts.

Even assuming the practicability of a fair degree of fire control through greatly increased expenditures, is the game worth the candle? The Forest Service men are a tough outfit and it takes a lot to make them admit they are licked, but the amount of taxpayers, money involved is so great that no false pride or saving of face should prevent a scrutiny of the justification of maintaining such expenditure when weighed against the values obtained, even though it involves an admission of defeat.

Almost any forester or lumberman would agree that the character of tree growth, soil and topography on the area in question is such that there is little likelihood of its being developed commercially in the future, even under a period of considerable timber scarcity; and even though a few of the best areas should sometime in the future be logged, the returns would at best be far below the annual expenditures, to say nothing of interest on past investment.

Recreational use and watershed protection are the only other values to be considered. It is conceded that these values would be enhanced by control of fires. However, the country in question in its natural state before the intervention of the Forest Service supported a 
fair forest cover and did not show any serious indications of watershed injury. Its special recreational values were probably greater than they are after thirty years of Forest Service management.

This leads up then to the third alternative of withdrawing all fire-control forces, stopping further expenditure for that purpose, and leaving the country pretty much to the forces of nature. It is a radical proposal, and could far better have been adopted ten years ago before the period of road construction started. Be that as it may, if a mistake has been made it is better to recognize it and change the mistaken policy than to plunge blindly ahead because a certain line of action has been started.

Much has been said and written about the abandonment of sub-marginal agricultural land. Should it not also be recognized that there is such a thing as sub-marginal forest land? Proper land classification and planning should lead us to radically different treatment of the wide range in classes of forest land. The good land will merit intensive treatment, the less good land less cultivation, and the least good lands something entirely different.

There has been enough money sunk, with little return, in the low-grade Selway wilderness to have acquired all the good cut-over and second-growth private forest land in Idaho, which is now a motherless orphan; and under present plans the Selway wilderness will annually swallow up enough funds for intensive management of these good forest lands.

Suppose the Forest Service should go to the proper committee in Congress and say, "We can save $\$ 300,000.00$ a year by withdrawing from attempted protection two million acres of low-grade land in Idaho. Permit us to use this amount for the acquisition, management, protection and planting of two million acres of the best Idaho forest land."
Wouldn't that sound like a reasonable thing to do?

The objection may be made that public opinion would not permit withdrawal of fire control from this area. Some day public opinion may rend the Forest Service for having accomplished so little protection with so much money. Public opinion can be moulded, and it is the job of foresters to lead public opinion in the right direction in forestry matters. Both as citizens and public officials it is the duty of the responsible men in the Forest Service to use the public funds wisely, and not to advocate expenditures that do not yield reasonable returns.

I am not advocating withdrawing protection from all low-value forest lands. It is conceded that it is a misfortune whenever fire sweeps any forested area, and while it is difficult to measure that damage in dollars it is certainly worth an expenditure within limits to prevent such fires. If the Forest Service could be assured of a reasonably adequate control of fire in the Selway country for two or three hundred thousand dollars a year I am inclined to believe that it would be worthwhile, even with little or no money return in sight. The trouble is that this country presents such an unusually difficult fire-control problem that even twice or thrice that amount will not insure any considerable reduction in the area which would burn without the attempted control, and a common-sense weighing of all factors indicates that it is time to withdraw from a losing game before more millions are expended with little or no results.

Reprinted with permission from Koch, E., 1935. The passing of the Lolo Trail. Journal of Forestry 33(2): 95-104. Copyright 1935 by the Society of American Foresters. 